\title{
Effect of Pedaling Rates and Myosin Heavy Chain Composition in the Vastus Lateralis Muscle on the Power Generating Capability during Incremental Cycling in Humans
}

\author{
J. MAJERCZAK ${ }^{1}$, Z. SZKUTNIK ${ }^{2,1}$, K. DUDA ${ }^{3,1}$, M. KOMOROWSKA ${ }^{4}$, \\ L. KOLODZIEJSKI ${ }^{3}$, J. KARASINSKI ${ }^{5}$, J. A. ZOLADZ ${ }^{1}$
}

${ }^{1}$ Department of Physiology and Biochemistry, Faculty of Rehabilitation, University School of Physical Education, ${ }^{2}$ Faculty of Applied Mathematics, AGH-University of Science and Technology, ${ }^{3}$ Cancer Institute, ${ }^{4}$ Department of Clinical Biochemistry, University Children Hospital, Faculty of Medicine, Jagiellonian University, ${ }^{5}$ Department of Cytology and Histology, Institute of Zoology, Jagiellonian University, Krakow, Poland

Received May 8, 2007

Accepted October 12, 2007

On-line November 30, 2007

\section{Summary}

In this study, we have determined power output reached at maximal oxygen uptake during incremental cycling exercise $\left(\mathrm{P}_{\mathrm{I}}, \max \right)$ performed at low and at high pedaling rates in nineteen untrained men with various myosin heavy chain composition (MyHC) in the vastus lateralis muscle. On separate days, subjects performed two incremental exercise tests until exhaustion at $60 \mathrm{rev} \cdot \mathrm{min}^{-1}$ and at $120 \mathrm{rev} \cdot \mathrm{min}^{-1}$. In the studied group of subjects $\mathrm{P}_{\mathrm{I} \text {, max }}$ reached during cycling at $60 \mathrm{rev} \cdot \mathrm{min}^{-1}$ was significantly higher $(p=0.0001)$ than that at $120 \mathrm{rev} \cdot \mathrm{min}^{-1}$ $\left(287 \pm 29\right.$ vs. $215 \pm 42 \mathrm{~W}$, respectively for 60 and $\left.120 \mathrm{rev} \cdot \mathrm{min}^{-1}\right)$. For further comparisons, two groups of subjects ( $n=6$, each) were selected according to $\mathrm{MyHC}$ composition in the vastus lateralis muscle: group $\mathrm{H}$ with higher MyHC II content $(56.8 \pm 2.79 \%)$ and group $L$ with lower MyHC II content in this muscle (28.6 $55.8 \%)$. $\mathrm{P}_{\mathrm{I} \text {, max }}$ reached during cycling performed at $60 \mathrm{rev} \cdot \mathrm{min}^{-1}$ in group $H$ was significantly lower than in group $L(p=0.03)$. However, during cycling at $120 \mathrm{rev} \cdot \mathrm{min}^{-1}$, there was no significant difference in $\mathrm{P}_{\mathrm{I} \text {, max }}$ reached by both groups of subjects $(\mathrm{p}=0.38)$. Moreover, oxygen uptake $\left(\mathrm{VO}_{2}\right)$, blood hydrogen ion $\left[\mathrm{H}^{+}\right]$, plasma lactate $\left[\mathrm{La}^{-}\right]$and ammonia $\left[\mathrm{NH}_{3}\right]$ concentrations determined at the four highest power outputs completed during the incremental cycling performed at 60 as well as $120 \mathrm{rev} \cdot \mathrm{min}^{-1}$, in the group $\mathrm{H}$ were significantly higher than in group $L$. We have concluded that during an incremental exercise performed at low pedaling rates the subjects with lower content of MyHC II in the vastus lateralis muscle possess greater power generating capabilities than the subjects with higher content of MyHC II. Surprisingly, at high pedaling rate, power generating capabilities in the subjects with higher MyHC II content in the vastus lateralis muscle did not differ from those found in the subjects with lower content of MyHC II in this muscle, despite higher blood $\left[\mathrm{H}^{+}\right],[\mathrm{La}]$ and $\left[\mathrm{NH}_{3}\right]$ concentrations. This indicates that at high pedaling rates the subjects with higher percentage of MyHC II in the vastus lateralis muscle perform relatively better than the subjects with lower percentage of MyHC II in this muscle.

\section{Key words}

Cycling • Myosin heavy chain isoforms • Muscle fatigue • Oxygen uptake

\section{Corresponding author}

J. Majerczak, Department of Physiology and Biochemistry, Faculty of Rehabilitation, University School of Physical Education, Al. Jana Pawla II 78, 31-571 Kraków, Poland. E-mail: joanna.majerczak@awf.krakow.pl

\section{Introduction}

During daily life activity human muscles generate broad range of power outputs and contract at various velocities (Sargeant and Jones 1995, Sargeant and de Haan 2006). It is well established that the maximal short-term muscle power output is strongly dependent upon the muscle contraction velocities (Sargeant et al. 1981, Sargeant and Beelen 1993). During cycling exercise the maximal power output is normally reached while cycling at about $120 \mathrm{rev} \cdot \mathrm{min}^{-1}$ (Sargeant et al. 1981, Sargeant and Beelen 1993, Sargeant and de Haan 
2006). However, the optimal shortening velocity at which the maximal power output can be reached varies between subjects, being highest in the subjects with high content of type II (fast) muscle fibers and lowest in those with high content of type I (slow) muscle fibers (Sargeant and Beelen 1993, Sargeant and Jones 1995, Aagaard and Andersen 1998).

Far less is known regarding the effect of muscle fibers composition on the power generating capabilities during maximal incremental cycling exercise performed at various pedaling rates. It should be mentioned that the incremental exercise protocols are the most frequently used procedures for assessment of maximal oxygen uptake $\left(\mathrm{VO}_{2 \max }\right)$ and the endurance capacity in humans (Astrand and Rodahl 1986, Wilmore and Costill 1999). In view of the available data (Sargeant and Beelen 1993, Sargeant and Jones 1995), cycling at the power output corresponding to maximal oxygen uptake requires recruitment of all available types of muscle fibers. However, during cycling at $120 \mathrm{rev} \cdot \mathrm{min}^{-1}$ the recruitment of type II muscle fibers starts earlier (i.e. at lower external power outputs), when compared to cycling at $60 \mathrm{rev} \cdot \mathrm{min}^{-1}$ (Sargeant 1994). Recruitment of the fatigue sensitive type II muscle fibers, characterized by lower metabolic stability (Matheson et al. 1991, Zoladz et al. 2006), causes greater muscle phosphocreatine and glycogen depletion as well as greater disturbances in muscle metabolites concentrations, i.e. the accumulation of $\left[\mathrm{ADP}_{\text {free }}\right],\left[\mathrm{P}_{\mathrm{i}}\right],[\mathrm{AMP}],\left[\mathrm{NH}_{3}\right],[\mathrm{IMP}],\left[\mathrm{H}^{+}\right]$which are the factors normally associated with fatigue (Dawson et al. 1980, Fitts 1994, Allen et al. 1995). This could be one of the reasons for the earlier fatigue while cycling at the same external power output with pedaling rates of 120 $\mathrm{rev} \cdot \mathrm{min}^{-1}$, when compared to the cycling at $60 \mathrm{rev} \cdot \mathrm{min}^{-1}$ (Beleen et al. 1993, Zoladz et al. 2000).

In the present study, we have hypothesized that the power generating capabilities during maximal incremental cycling exercise performed at the pedaling rate of $60 \mathrm{rev} \cdot \mathrm{min}^{-1}$ and at $120 \mathrm{rev} \cdot \mathrm{min}^{-1}$ (similar to sprinting, see e.g. Sargeant and Beelen 1993, Sargeant and Jones 1995) will also be related to the content of various types of myosin heavy chain isoforms (MyHC I and MyHC II) in the vastus lateralis muscle in humans, which corresponds to the proportion of type I and type II (slow and fast) muscle fibers (Fry et al. 1994, Aagaard and Andersen 1998). To our best knowledge, no studies were conducted to examine such a relationship. Our assumption is based on the earlier findings showing that the pedaling rate of $60 \mathrm{rev} \mathrm{min}^{-1}$ is closer to the optimal velocity of shortening for type I muscle fibers, whereas pedaling rate of $120 \mathrm{rev} \cdot \mathrm{min}^{-1}$ is closer to the optimal velocity of shortening for type II muscle fibers (Sargeant and Jones 1995). Therefore, in the present study, we have hypothesized that the subjects with higher content of MyHC II in the vastus lateralis muscle will perform relatively better at $120 \mathrm{rev} \cdot \mathrm{min}^{-1}$ than at $60 \mathrm{rev} \cdot \mathrm{min}^{-1}$, when compared to the subjects with lower content of MyHC II in this muscle.

\section{Subjects and Methods}

\section{Subjects}

Nineteen untrained, but physically active, nonsmoking men (mean \pm SD: age $23.7 \pm 2.6$ years; body mass $72.4 \pm 6.8 \mathrm{~kg}$; height $178.9 \pm 4.7 \mathrm{~cm}$; BMI $22.61 \pm 1.91$ $\mathrm{kg} \cdot \mathrm{m}^{-2} ; \mathrm{VO}_{2 \max } 50.2 \pm 5.1 \mathrm{ml} \cdot \mathrm{kg}^{-1} \cdot \mathrm{min}^{-1}$ ) participated in this study. Subjects gave informed written consent and were aware of the aims of the study. The study protocol was approved by the Local Ethical Committee and was performed in accordance with the Declaration of Helsinki. Since the subjects had only little experience with cycling, especially at high frequencies i.e. $120 \mathrm{rev}$ $\min ^{-1}$, one week before starting the main exercise protocols they visited the laboratory in order to practice cycling at this frequency for about 6-10 minutes.

\section{Exercise protocol}

The incremental exercise test was performed on the cycloergometer Ergo-Line $\mathrm{GmbH} \& \mathrm{Co} \mathrm{KG} 800$ s (Bitz, Germany). Before the test, a 6-min resting period was allowed to determine the resting stage of the cardiorespiratory parameters, as well as to withdraw the blood samples. The exercise test started at power output $30 \mathrm{~W}$, followed by gradual increase amounting to $30 \mathrm{~W}$ every 3 min and it was continued until exhaustion. The incremental test was performed on separate days at two different pedaling rates: 60 and $120 \mathrm{rev} \cdot \mathrm{min}^{-1}$ in the stable conditions, i.e. air temperature of about $22{ }^{\circ} \mathrm{C}$ and relative humidity of about $50 \%$.

\section{Gas exchange variables}

Gas exchange variables were measured continuously breath by breath using the Oxycon Champion, Mijnhardt BV (Bunnik, The Netherlands), starting from the sixth minute prior to exercise until the test was stopped. Before and after each test, gas analyzers were calibrated with certificated calibration gases, as previously described by Zoladz et al. (1995). 


\section{Blood sampling}

Blood samples were taken using an Abbot IntCatheter, Ireland $(18 \mathrm{G} / 1.2 \mathrm{x} 45 \mathrm{~mm})$ inserted into the antecubital vein about $15 \mathrm{~min}$ prior to the onset of the exercise. The catheter was connected to an extension set using a "T" Adapter SL Abbot, Ireland (the tube $10 \mathrm{~cm}$ in length). Immediately before taking each blood samples, $1 \mathrm{ml}$ of blood was taken in order to eliminate blood from the catheter and the T-set. Blood samples for blood gases and hydrogen ion concentration as well as plasma lactate and ammonia concentrations were taken prior to the exercise test, at the end of each step of the incremental exercise (the last $15 \mathrm{~s}$ before increase of power output) and at the moment of ending the exercise protocol. Blood samples for plasma potassium concentration were taken prior and at the end of the exercise protocol.

\section{Hydrogen ion concentration, $\mathrm{PO}_{2}$ and $\mathrm{PCO}_{2}$}

Blood partial pressure of oxygen $\left(\mathrm{PO}_{2}\right)$ and carbon dioxide $\left(\mathrm{PCO}_{2}\right)$ as well as hydrogen ion concentration $\left[\mathrm{H}^{+}\right]$ were determined using a Ciba-Corning analyzer 248 (England). Blood bicarbonate concentration $\left[\mathrm{HCO}_{3}{ }^{-}\right]$was calculated by this unit.

\section{Plasma lactate measurements}

The blood samples for plasma lactate concentration [ $\left.\mathrm{La}^{-}\right](0.5 \mathrm{ml}$ each $)$ were placed in $1.8 \mathrm{ml}$ Eppendorf tubes containing $1 \mathrm{mg}$ ammonium oxalate and $5 \mathrm{mg}$ sodium fluoride and mixed for about $20 \mathrm{~s}$ and then centrifuged at $4000 \mathrm{rev} \cdot \mathrm{min}^{-1}$ for $4 \mathrm{~min}$. The obtained samples of blood plasma $(200 \mu \mathrm{l})$ were stored at $-32{ }^{\circ} \mathrm{C}$ for further analysis of lactate concentration using an automatic analyzer Vitros 250 Dry Chemistry System, Kodak (Rochester, NY, USA). Detection limit was $0.5 \mathrm{mmol} \cdot 1^{-1}$. Lactate threshold (LT) in this study was defined as the highest power output above which plasma lactate concentration showed a sustained increase of more than $0.5 \mathrm{mmol} \cdot \mathrm{l}^{-1} \cdot \mathrm{step}^{-1}$ (Zoladz et al. 1995). Lactate threshold was identified in the incremental exercise test performed at $60 \mathrm{rev} \cdot \mathrm{min}^{-1}$. During cycling at $120 \mathrm{rev}$. $\min ^{-1}$ LT was not detected, because sharp increase in lactate concentration was present already from the first power output i.e. from $30 \mathrm{~W}$.

\section{Plasma ammonia measurements}

The blood samples for plasma ammonia concentration $\left[\mathrm{NH}_{3}\right]$ measurements were placed in $1.3 \mathrm{ml}$ tube with lithium heparin, collected on ice till the end of exercise and then centrifuged at $4000 \mathrm{rev} \cdot \mathrm{min}^{-1}$ for
$3 \mathrm{~min}$. The obtained samples of blood plasma were stored at $-32{ }^{\circ} \mathrm{C}$ for further analysis of ammonia concentration using an automatic analyzer Vitros 250 Dry Chemistry System, Kodak (Rochester, NY, USA) after conversion of ammonium ions $\left[\mathrm{NH}_{4}^{+}\right]$into gaseous ammonia $\left[\mathrm{NH}_{3}\right]$. Detection limit was $1.0 \mu \mathrm{mol} \cdot 1^{-1}$.

\section{Plasma potassium measurements}

The blood samples for plasma potassium concentration $\left[\mathrm{K}^{+}\right]$measurements were placed in $1.3 \mathrm{ml}$ tube with lithium heparin and after exercise protocol centrifuged at $4000 \mathrm{rev} \cdot \mathrm{min}^{-1}$ for $3 \mathrm{~min}$. Plasma venous potassium concentration $\left[\mathrm{K}^{+}\right]$was determined using Chiron Diagnostic $644 \mathrm{Na}^{+} / \mathrm{K}^{+} / \mathrm{Cl}^{-}$analyzer, U.K.

\section{Muscle biopsy}

Muscle biopsy samples were taken from the vastus lateralis $\mathrm{m}$. quadricipitis femoris $15 \mathrm{~cm}$ above the upper margin of patella, under local anesthesia (1\% lidocaine), using $5 \mathrm{~mm}$ Bergström needle. Specimens were frozen and stored in liquid nitrogen until further analyses.

\section{Myosin extraction}

Muscle biopsies were mounted in Shandon cryostat with Tissue-Tek and 30-50 cryosections, $30 \mu \mathrm{m}$ thick, were cut from each biopsy. Sections were transferred to Eppendorf tubes and myosin was extracted with 200-300 $\mu \mathrm{l}$ of lysing buffer consisting of $62.5 \mathrm{mM}$ Tris, $10 \%$ glycerol, $5 \%$ 2-mercaproethanol, $2.3 \%$ SDS, pH 6.8 (Andersen and Aagaard 2000). Samples were briefly vortexed and boiled for $3 \mathrm{~min}$ in water bath. Myosin extracts were clarified at $13000 \times \mathrm{g}$ for $5 \mathrm{~min}$ and supernatants were freezed at $-20{ }^{\circ} \mathrm{C}$ until further use.

\section{$S D S-P A G E$}

SDS-polyacrylamide gel electrophoresis was carried out according to Carraro and Catani (1983) with $3 \%$ stacking gel and $6 \%$ separating gel containing $37.5 \%$ glycerol, in Mini-Protean II electrophoresis system (Bio-Rad Laboratories, Hercules, USA). Myosin extracts were diluted 1:1 with sample buffer containing $0.1 \mathrm{M} \quad$ Tris- $\mathrm{HCl} \quad \mathrm{pH} \quad 6.8, \quad 2.5 \% \quad$ SDS, $2.5 \%$ 2-mercaptoethanol and boiled for $3 \mathrm{~min}$. Myosin extracts, diluted 1:10 - 1:20 with lysing buffer, were loaded onto stacking gel and run at a constant voltage of $60 \mathrm{~V}$ for 30 min and then at $180 \mathrm{~V}$ for $3 \mathrm{~h}$. Densitometric analysis of protein bands was performed using a video camera Fotodyne Incorporated and computer software Gel Pro Analyzer. Relative amounts of MyHC protein were 
expressed in optical density units (OD).

\section{Data analysis}

In this study, the exercise-induced changes (the difference between end-exercise and rest value) in the gas exchange variables as well as in blood $\left[\mathrm{H}^{+}\right],\left[\mathrm{HCO}_{3}{ }^{-}\right]$, $\left[\mathrm{La}^{-}\right],\left[\mathrm{NH}_{3}\right],\left[\mathrm{K}^{+}\right]$were analyzed during incremental cycling at 60 and $120 \mathrm{rev} \cdot \mathrm{min}^{-1}$ in the whole group of nineteen subjects as well as in two different subgroups of subjects ( $\mathrm{n}=6$, each): the group $\mathrm{H}$ with the higher content of MyHC II in the vastus lateralis muscle and the group L with the lower content of MyHC II in this muscle (see Results). Statistical significance was tested using Wilcoxon-signed-rank test (for paired samples; nonasymptotic, exact, two-sided p-values are presented) and Wilcoxon-Mann-Whitney test (for two independent samples; non-asymptotic exact, two-sided p-values are presented).

The oxygen uptake $\left(\mathrm{VO}_{2}\right)$ as well as $\left[\mathrm{H}^{+}\right]$, $\left[\mathrm{HCO}_{3}{ }^{-}\right],\left[\mathrm{La}^{-}\right]$and $\left[\mathrm{NH}_{3}\right]$ were analyzed in the group $\mathrm{H}$ and $\mathrm{L}$ in the range of the four highest power outputs completed during cycling at $60 \mathrm{rev} \cdot \mathrm{min}^{-1}$ and during cycling at $120 \mathrm{rev} \cdot \min ^{-1}$ (i.e. $180-270 \mathrm{~W}$ and $90-180 \mathrm{~W}$, respectively for pedaling rates 60 and $120 \mathrm{rev} \cdot \mathrm{min}^{-1}$ ). During an incremental cycling at $60 \mathrm{rev} \cdot \mathrm{min}^{-1}, 270 \mathrm{~W}$ was the highest completed power output obtained by all subjects from group $\mathrm{L}$ and by four subjects from group $\mathrm{H}$ (for two of them the highest power output was 260 and $265 \mathrm{~W}$, data included to the analysis). During an incremental cycling at $120 \mathrm{rev} \cdot \mathrm{min}^{-1}$, the last power output (i.e. $180 \mathrm{~W}$ ) was completed by five subjects from group $\mathrm{H}$ and by five subjects from group $\mathrm{L}$. Since the changes in $\left[\mathrm{H}^{+}\right],\left[\mathrm{HCO}_{3}{ }^{-}\right],\left[\mathrm{La}^{-}\right]$and $\left[\mathrm{NH}_{3}\right]$ in the range of power outputs given above were non-linear (Figs 2-5), we have transformed the original data to logarithmic scale, in order to be able to perform valid analysis of covariance (ANCOVA). In the first step of analysis, we tested equality of slopes in the group $\mathrm{H}$ and $\mathrm{L}$ (parallelism test) of the linear dependencies between power output (in the ranges $180-270 \mathrm{~W}$ and $90-180 \mathrm{~W}$, respectively for pedaling rates 60 and $120 \mathrm{rev} \cdot \mathrm{min}^{-1}$ ) and the chosen variable (i.e. $\mathrm{VO}_{2}, \log \left[\mathrm{H}^{+}\right], \log \left[\mathrm{HCO}_{3}{ }^{-}\right]$, $\left.\log \left[\mathrm{La}^{-}\right], \log \left[\mathrm{NH}_{3}\right]\right)$, separately for pedaling rate 60 and $120 \mathrm{rev} \cdot \mathrm{min}^{-1}$. Since the hypotheses of identical slopes in the groups $\mathrm{H}$ and $\mathrm{L}$ have not been rejected, ANCOVA was then used with one factor only, i.e. the MyHC II content in the vastus lateralis muscle, to test the equality of the intercepts (Seber 1977). This was done separately for 60 and $120 \mathrm{rev} \cdot \mathrm{min}^{-1}$.
The analysis was performed using the statistical packages STATISTICA 7.1 and StatXact 6.1.

\section{Results}

\section{MyHC composition in the vastus lateralis muscle}

Densitometric analysis of MyHC I and MyHC II resolved in polyacrylamide gel showed that in the group of nineteen subjects mean content of MyHC I was $57.1 \pm 12.4 \%$ and mean content of MyHC II was $42.9 \pm 12.4 \%$. From the group of nineteen subjects two extreme groups of subjects ( $\mathrm{n}=6$, each), according to the expression of MyHC II in the vastus lateralis muscle, were selected. The group $\mathrm{H}$ with the significantly $(\mathrm{p}=0.002)$ higher content of MyHC II (mean value of MyHC II 56.8 $\pm 2.8 \%$ ) and the second group called L with the lower proportion of MyHC II (mean value of MyHC II $28.6 \pm 5.8 \%$ ).

The body mass index of the subjects from group $\mathrm{H}$ was not significantly different from BMI of subjects from group L ( $21.6 \pm 0.8 v s .23 .7 \pm 2.6 \mathrm{~kg} \cdot \mathrm{m}^{-2}$, respectively for the group $\mathrm{H}$ and $\mathrm{L} ; \mathrm{p}=0.18$ ). There was a tendency to lower power output reached at lactate threshold during cycling at $60 \mathrm{rev} \cdot \mathrm{min}^{-1}$ in group $\mathrm{H}$ when compared to group L ( $165 \pm 16$ vs. $140 \pm 15 \mathrm{~W}$, respectively for the group $\mathrm{H}$ and $\mathrm{L}, \mathrm{p}=0.08$ ).

Maximal oxygen uptake and power output reached at maximal oxygen uptake during cycling at 60 and $120 \mathrm{rev}$. $\mathrm{min}^{-1}$ in the group of nineteen subjects as well as in the groups $H$ and $L$

Maximal oxygen uptake $\left(\mathrm{VO}_{2 \max }\right)$ in the group of nineteen subjects when cycling at $120 \mathrm{rev} \cdot \mathrm{min}^{-1}$ was not significantly different $(\mathrm{p}=0.30)$ from $\mathrm{VO}_{2 \max }$ reached during cycling performed at $60 \mathrm{rev} \cdot \mathrm{min}^{-1}(3663 \pm 413 \mathrm{vs}$. $3622 \pm 376 \mathrm{ml} \cdot \mathrm{min}^{-1}$, respectively for the $120 \mathrm{rev} \cdot \mathrm{min}^{-1}$ and $\left.60 \mathrm{rev} \cdot \mathrm{min}^{-1}\right)$. Maximal oxygen uptake reached during cycling at $60 \mathrm{rev} \cdot \mathrm{min}^{-1}$ in subjects from group $\mathrm{H}$ was not significantly different $(\mathrm{p}=0.60)$ from $\mathrm{VO}_{2 \max }$ of subjects from group L $(3667 \pm 187$ vs. $3784 \pm 257$ $\mathrm{ml} \cdot \mathrm{min}^{-1}$, respectively for the group $\mathrm{H}$ and $\mathrm{L}$ ). Moreover, no significant difference $(\mathrm{p}=0.24)$ in $\mathrm{VO}_{2 \max }$ between subjects from both groups was found during cycling at $120 \mathrm{rev} \cdot \min ^{-1}\left(3565 \pm 203\right.$ vs. $3774 \pm 269 \mathrm{ml} \cdot \min ^{-1}$, respectively for the group $\mathrm{H}$ and $\mathrm{L}$ ).

In the group of nineteen subjects, the power output obtained at $\mathrm{VO}_{2 \max }\left(\mathrm{P}_{\mathrm{I}}, \max \right)$ during cycling at $120 \mathrm{rev} \cdot \mathrm{min}^{-1}$ was significantly lower $(\mathrm{p}=0.0001)$ than $\mathrm{P}_{\mathrm{I}, \max }$ obtained during cycling at $60 \mathrm{rev} \cdot \min ^{-1}(215 \pm 42$ 


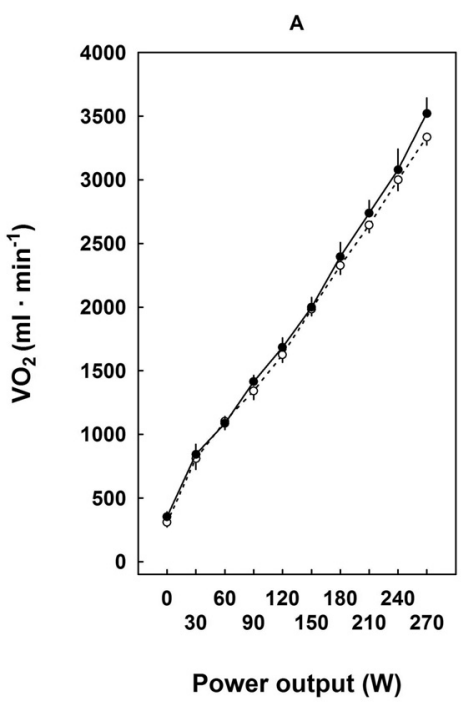

A

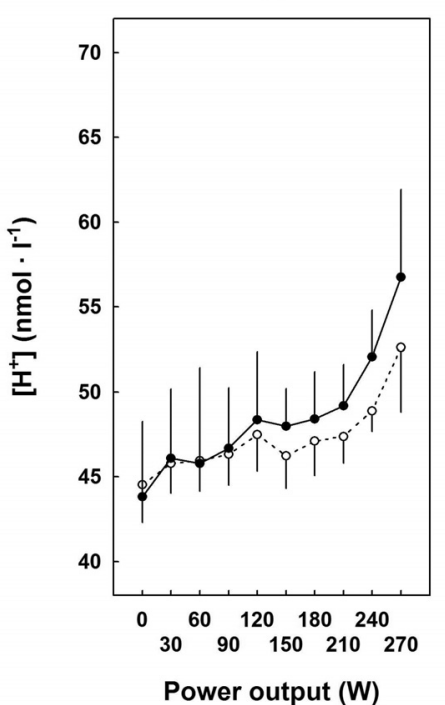

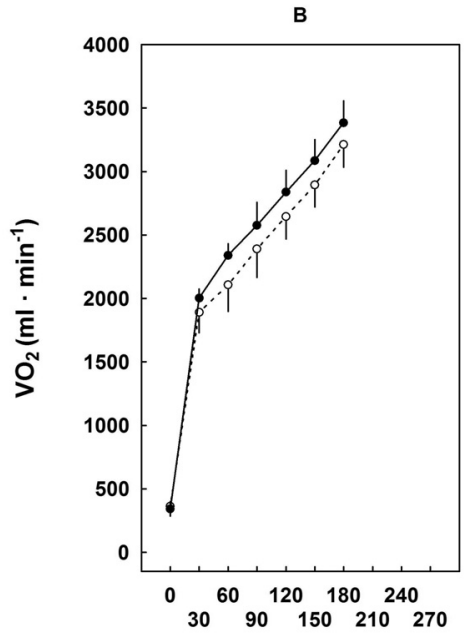

Power output (W)

B

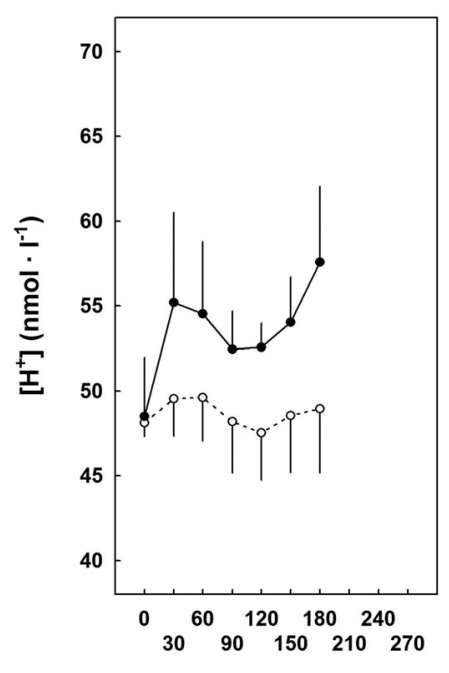

Power output (W)
Fig. 1. A. The oxygen uptake/power output relationship during incremental cycling in the range $30-270 \mathrm{~W}$ performed at $60 \mathrm{rev} \cdot \mathrm{min}^{-1}$ for the group $\mathrm{H}(\bullet)$ and for the group $\mathrm{L}\left({ }^{\circ}\right)$. Data presented as mean value \pm S.D. at each power output, for $\mathrm{n}=6$ subjects in both groups ( $\mathrm{H}$ and L). A significantly higher oxygen uptake in the range of power outputs $180-270 \mathrm{~W}$ in the group $\mathrm{H}$ was found when compared to the group $L$ (ANCOVA, $p=0.0005$ ). B. The oxygen uptake/power output relationship during incremental cycling in the range 30-180 W performed at $120 \mathrm{rev} \cdot \mathrm{min}^{-1}$ for the group $\mathrm{H}$ $(\bullet)$ and for the group $L\left({ }^{\circ}\right)$. Data presented as mean value \pm S.D. at each power output, for $\mathrm{n}=6$ subjects in both groups ( $\mathrm{H}$ and $\mathrm{L}) . A$ tendency to higher oxygen uptake in the range of power outputs $90-180 \mathrm{~W}$ in the group $\mathrm{H}$ was found when compared to the group $L$ (ANCOVA, $p=0.069$ ).

Fig. 2. A. The hydrogen ion concentration/ power output relationship during incremental cycling in the range $30-270 \mathrm{~W}$ performed at 60 rev $\min ^{-1}$ for the group $\mathrm{H}(\bullet)$ and for the group $L(\circ)$. Data presented as mean value \pm S.D. at each power output, for $n=6$ subjects in both groups $(\mathrm{H}$ and $\mathrm{L})$. A significantly higher blood hydrogen ion concentration in the range of power outputs $180-270 \mathrm{~W}$ in the group $\mathrm{H}$ was found when compared to the group $L$ (ANCOVA, $p=0.004$ ). B. The blood hydrogen ion concentration/ power output relationship during incremental cycling in the range 30-180 W performed at $120 \mathrm{rev} \cdot \mathrm{min}^{-1}$ for the group $\mathrm{H}$ $(\bullet)$ and for the group $L\left({ }^{\circ}\right)$. Data presented as mean value \pm S.D. at each power output, for $\mathrm{n}=6$ subjects in both groups $(\mathrm{H}$ and $\mathrm{L})$. A significantly higher blood hydrogen ion concentration in the range of power outputs 90-180 $\mathrm{W}$ in the group $\mathrm{H}$ was found when compared to the group $L$ (ANCOVA, $p<10^{-4}$ ). vs. $287 \pm 29 \mathrm{~W}$, respectively for 120 and $60 \mathrm{rev} \cdot \mathrm{min}^{-1}$ ). This reduction in power output obtained at $\mathrm{VO}_{2 \max }$ due to increase in pedaling rates from 60 to $120 \mathrm{rev} \cdot \mathrm{min}^{-1}$ amounted to $72 \pm 39 \mathrm{~W}$, i.e. $\mathrm{P}_{\mathrm{I}, \max }$ at $120 \mathrm{rev} \cdot \mathrm{min}^{-1}$ was about $25 \%$ lower when compared to $60 \mathrm{rev} \cdot \mathrm{min}^{-1}$. Moreover, in this group of subjects $(n=19)$ the oxygen cost of generating $\mathrm{P}_{\mathrm{I}, \max }\left(\mathrm{VO}_{2} / \mathrm{P}_{\mathrm{I} \text {, max }}\right)$ during cycling at $120 \mathrm{rev} \cdot \mathrm{min}^{-1}$ was significantly higher $(\mathrm{p}=0.009)$ than $\mathrm{VO}_{2} / \mathrm{P}_{\mathrm{I} \text {, max }}$ during cycling at $60 \mathrm{rev} \cdot \mathrm{min}^{-1}$ (15.8 $\pm 2.3 \mathrm{vs}$. $11.5 \pm 0.6 \mathrm{ml} \cdot \mathrm{min}^{-1} \cdot \mathrm{W}^{-1}$, respectively for 120 and $60 \mathrm{rev}$. $\left.\min ^{-1}\right)$.

Power output obtained at $\mathrm{VO}_{2 \max }$ during cycling at $60 \mathrm{rev} \cdot \mathrm{min}^{-1}$ for the subjects from group $\mathrm{H}$ was significantly lower $(p=0.032)$ when compared to $P_{I}$, max obtained for subjects from group L (279 \pm 16 vs. 303 $\pm 17 \mathrm{~W}$, respectively for the group $\mathrm{H}$ and $\mathrm{L}$ ). However, during cycling at $120 \mathrm{rev} \cdot \mathrm{min}^{-1}, \mathrm{P}_{\mathrm{I} \text {, max }}$ obtained in the group $\mathrm{H}$ was not significantly different $(\mathrm{p}=0.38)$, from $\mathrm{P}_{\mathrm{I}}$, max obtained in the group $\mathrm{L}(204 \pm 31$ vs. $224 \pm 38 \mathrm{~W}$, respectively for the group $\mathrm{H}$ and $\mathrm{L}$ ). The reduction in $\mathrm{P}_{\mathrm{I}}$, ${ }_{\max }$, due to increasing pedaling rates from $60 \mathrm{rev} \cdot \mathrm{min}^{-1}$ to $120 \mathrm{rev} \mathrm{min}^{-1}$ for the subjects from group $\mathrm{H}$ and $\mathrm{L}$ was not significantly different and amounted to about $25 \%$ $(\mathrm{p}=1.0)$.

Oxygen uptake, blood hydrogen ion and bicarbonate concentrations, plasma lactate and plasma ammonia concentrations during incremental cycling at 60 and $120 \mathrm{rev} \cdot \mathrm{min}^{-1}$ in the group $H$ and in the group $L$

\section{Oxygen uptake $\left(\mathrm{VO}_{2}\right)$}

Oxygen uptake for the groups $\mathrm{H}$ and $\mathrm{L}$ reached during an incremental cycling at $60 \mathrm{rev} \cdot \mathrm{min}^{-1}$ is presented in Figure 1A. Oxygen uptake in the range of 

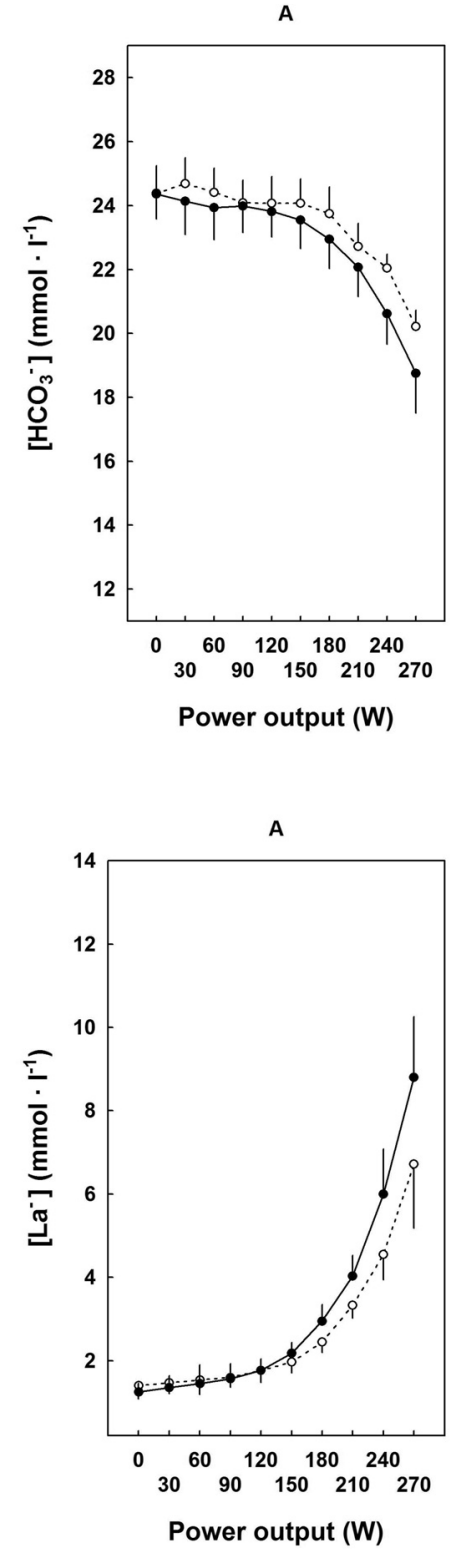
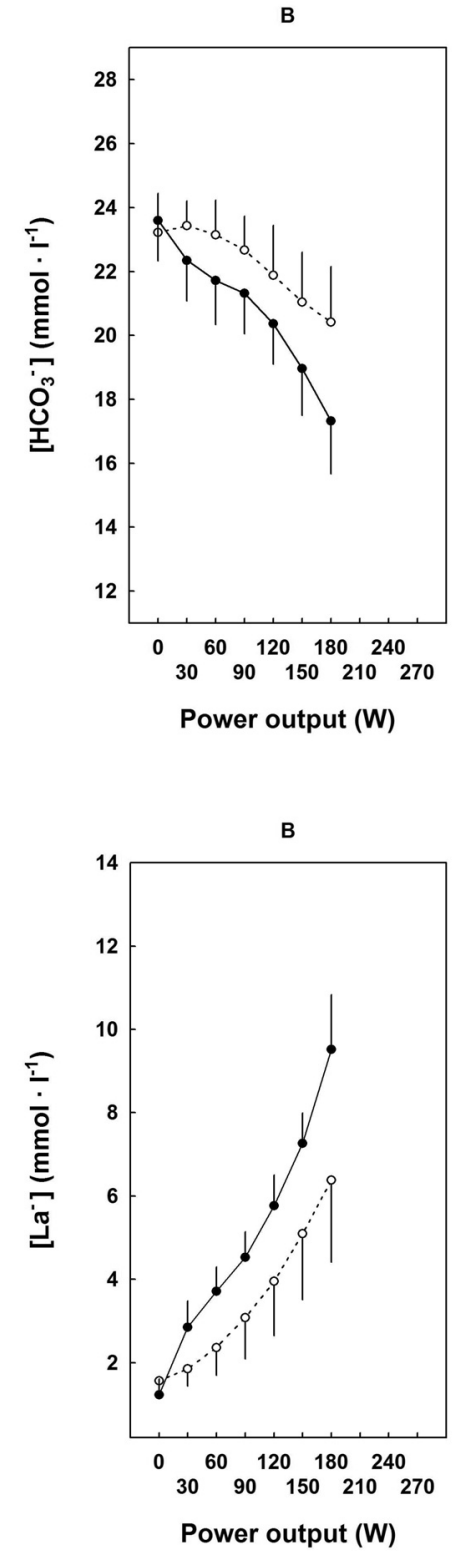

Fig. 3. A. The blood bicarbonate concentration/power output relationship during incremental cycling in the range 30-270 W performed at $60 \mathrm{rev} \cdot \mathrm{min}^{-1}$ for the group $\mathrm{H}(\bullet)$ and for the group L. Data presented as mean value \pm S.D. at each power output, for $n=6$ subjects in both groups $(\mathrm{H}$ and $\mathrm{L})$. A significantly lower blood bicarbonate concentration in the range of power outputs $180-270 \mathrm{~W}$ in the group $\mathrm{H}$ was found when compared to the group L (ANCOVA, $\mathrm{p}=0.0001)$. B. The blood bicarbonate concentration/power output relationship during incremental cycling in the range 30-180 W performed at $120 \mathrm{rev} \cdot \mathrm{min}^{-1}$ for the group $\mathrm{H}$ $(\bullet)$ and for the group $L\left({ }^{\circ}\right)$. Data presented as mean value \pm S.D. at each power output, for $n=6$ subjects in both groups $(H$ and $L)$. A significantly lower blood bicarbonate concentration in the range of power outputs 90-180 $W$ in the group $H$ was found when compared to the group $L$ (ANCOVA, $p<10^{-4}$ ).

Fig. 4. A. The plasma lactate concentration/ power output relationship during incremental cycling in the range 30-270 W performed at 60 rev $\min ^{-1}$ for the group $H(\bullet)$ and for the group $L(\circ)$. Data presented as mean value \pm S.D. at each power output, for $n=6$ subjects in both groups ( $\mathrm{H}$ and $\mathrm{L})$. A significantly higher plasma lactate concentration in the range of power outputs $180-270 \mathrm{~W}$ in the group $\mathrm{H}$ was found when compared to the group $L$ (ANCOVA, $\mathrm{p}<10^{-4}$ ). B. The plasma lactate concentration/power output relationship during incremental cycling in the range 30-180 W performed at $120 \mathrm{rev} \cdot \mathrm{min}^{-1}$ for the group $\mathrm{H}$ $(\bullet)$ and for the group $L(\circ)$. Data presented as mean value \pm S.D. at each power output, for $n=6$ subjects in both groups $(H$ and $L)$. A significantly higher plasma lactate concentration in the range of power outputs 90-180 $\mathrm{W}$ in the group $\mathrm{H}$ was found when compared to the group $L$ (ANCOVA, $p<10^{-4}$ ). power outputs $180-270 \mathrm{~W}$ was significantly higher in the group $\mathrm{H}$ than in the group $\mathrm{L}$ (ANCOVA, $\mathrm{F}=14.1$; $\mathrm{p}=0.0005)$.

Oxygen uptake for the groups $\mathrm{H}$ and $\mathrm{L}$ reached during an incremental cycling at $120 \mathrm{rev} \cdot \mathrm{min}^{-1}$ is presented in Figure 1B. The tendency to the higher oxygen uptake in the range of power outputs 90-180 W was observed in the group $\mathrm{H}$, when compared to the group L (ANCOVA, F=3.5; $\mathrm{p}=0.069$ ).

\section{Blood hydrogen ion concentration $\left[\mathrm{H}^{+}\right]$}

Blood hydrogen ion concentration for the groups $\mathrm{H}$ and $\mathrm{L}$ reached during an incremental cycling at 60 rev $\min ^{-1}$ is presented in Figure $2 \mathrm{~A}$. Blood hydrogen ion concentration in the range of power outputs $180-270 \mathrm{~W}$ was significantly higher in the group $\mathrm{H}$ than in the group L (ANCOVA, $\mathrm{F}=9.4 ; \mathrm{p}=0.004$ ).
Blood hydrogen ion concentration for the groups $\mathrm{H}$ and $\mathrm{L}$ reached during an incremental cycling at $120 \mathrm{rev}$ $\min ^{-1}$ is presented in Figure 2B. Blood hydrogen ion concentration in the range of power outputs $90-180 \mathrm{~W}$ was significantly higher in the group $\mathrm{H}$ than in the group L (ANCOVA, $\mathrm{F}=43.3 ; \mathrm{p}<10^{-4}$ ).

\section{Blood bicarbonate concentration $\left[\mathrm{HCO}_{3}^{-}\right]$}

Blood bicarbonate concentration for the groups $\mathrm{H}(\bullet)$ and $\mathrm{L}\left({ }^{\circ}\right)$ reached during an incremental cycling at $60 \mathrm{rev} \cdot \mathrm{min}^{-1}$ is presented in Figure 3A. Blood bicarbonate concentration in the range of power outputs $180-270 \mathrm{~W}$ was significantly lower in the group $\mathrm{H}$ than in the group L (ANCOVA, $\mathrm{F}=18.1 ; \mathrm{p}=0.0001$ ).

Blood bicarbonate concentration for the groups $\mathrm{H}(\bullet)$ and $\mathrm{L}\left({ }^{\circ}\right)$ reached during an incremental cycling at $120 \mathrm{rev} \cdot \mathrm{min}^{-1}$ is presented in Figure 3B. Blood 


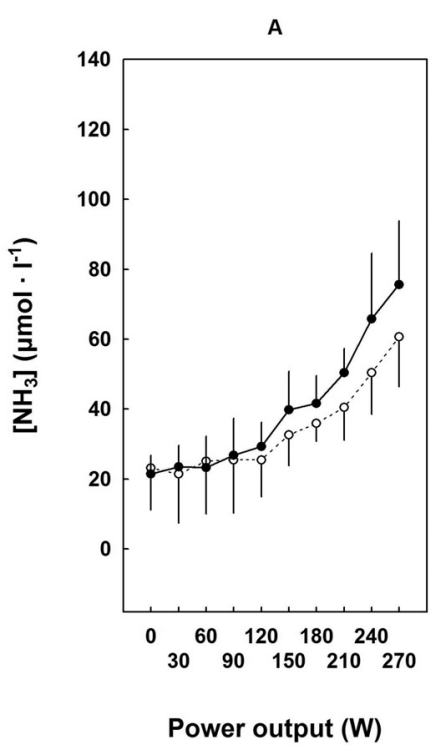

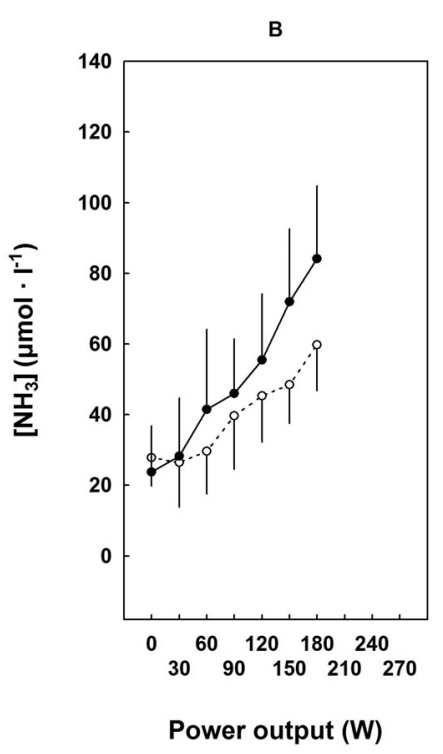

Fig. 5. A. The plasma ammonia concentration/power output relationship during incremental cycling in the range 30-270 W performed at $60 \mathrm{rev} \cdot \mathrm{min}^{-1}$ for the group $\mathrm{H}(\bullet)$ and for the group $L(\circ)$. Data presented as mean value \pm S.D. at each power output, for $\mathrm{n}=6$ subjects in both groups $(\mathrm{H}$ and $\mathrm{L})$. $A$ significantly higher plasma ammonia concentration in the range of power outputs $180-270 \mathrm{~W}$ in the group $\mathrm{H}$ was found when compared to the group L (ANCOVA, $p=0.0007)$. B. The plasma ammonia concentration/power output relationship during incremental cycling in the range 30$180 \mathrm{~W}$ performed at $120 \mathrm{rev} \cdot \mathrm{min}^{-1}$ for the group $\mathrm{H}(\bullet)$ and for the group $L\left({ }^{\circ}\right)$. Data presented as mean value \pm S.D. at each power output, for $n=6$ subjects in both groups ( $\mathrm{H}$ and $\mathrm{L}$ ). A significantly higher plasma ammonia concentration in the range of power outputs $90-180 \mathrm{~W}$ in the group $\mathrm{H}$ was found when compared to the group L (ANCOVA, $\mathrm{p}=0.001$ ). bicarbonate concentration in the range of power outputs 90-180 W was significantly lower in the group $\mathrm{H}$ than in the group L (ANCOVA, F=21.5; $<<10^{-4}$ ).

\section{Plasma lactate concentration [ $\left.\mathrm{La}^{-}\right]$}

Plasma lactate concentration for the groups $\mathrm{H}$ and $\mathrm{L}$ reached during an incremental cycling at 60 rev $\min ^{-1}$ is presented in Figure 4A. Plasma lactate concentration in the range of power outputs $180-270 \mathrm{~W}$ was significantly higher in the group $\mathrm{H}$ than in the group L (ANCOVA, F=33.3; $\mathrm{p}<10^{-4}$ ).

Plasma lactate concentration for the groups $\mathrm{H}$ and $\mathrm{L}$ reached during an incremental cycling at 120 rev $\min ^{-1}$ is presented in Figure 4B. Plasma lactate concentration in the range of power outputs 90-180 W was significantly higher in the group $\mathrm{H}$ than in the group L (ANCOVA, $F=38.6 ; \mathrm{p}<10^{-4}$ ).

\section{Plasma ammonia concentration $\left[\mathrm{NH}_{3}\right]$}

Plasma ammonia concentration for the groups $\mathrm{H}$ and $\mathrm{L}$ reached during an incremental cycling at 60 rev $\mathrm{min}^{-1}$ is presented in Figure 5A. Plasma ammonia concentration in the range of power outputs $180-270 \mathrm{~W}$ was significantly higher in the group $\mathrm{H}$ than in the group L (ANCOVA, F=13.1; $\mathrm{p}=0.0007$ ).

Plasma ammonia concentration for the groups $\mathrm{H}$ and $\mathrm{L}$ reached during an incremental cycling at 120 rev $\min ^{-1}$ is presented in Figure 5B. Plasma ammonia concentration in the range of power outputs 90-180 W was significantly higher in the group $\mathrm{H}$ than in the group L (ANCOVA, $\mathrm{F}=12.0 ; \mathrm{p}=0.001)$.
Exercise-induced changes in gas exchange variables and in blood $\left[\mathrm{H}^{+}\right], \quad\left[\mathrm{HCO}_{3}^{-}\right], \quad\left[\mathrm{La}^{-}\right], \quad\left[\mathrm{NH}_{3}\right], \quad\left[\mathrm{K}^{+}\right]$ concentrations during cycling at 60 and $120 \mathrm{rev} \mathrm{min}^{-1}$ in the group of nineteen subjects

The exercise-induced changes $(\Delta)$ in gas exchange variables, i.e. oxygen uptake $\left(\mathrm{VO}_{2}\right)$, carbon dioxide production $\left(\mathrm{VCO}_{2}\right)$ and minute ventilation $\left(\mathrm{V}_{\mathrm{E}}\right)$ as well as in blood $\left[\mathrm{H}^{+}\right],\left[\mathrm{La}^{-}\right],\left[\mathrm{NH}_{3}\right],\left[\mathrm{K}^{+}\right]$concentrations during cycling at 60 and $120 \mathrm{rev} \cdot \mathrm{min}^{-1}$ in the group of nineteen subjects are presented in Table 1 . In the group of nineteen subjects when cycling at $120 \mathrm{rev} \cdot \mathrm{min}^{-1}$ significantly higher $\Delta \mathrm{V}_{\mathrm{E}}(\mathrm{p}=0.007)$, higher $\Delta\left[\mathrm{H}^{+}\right](\mathrm{p}=0.008)$ and the tendency to higher $\Delta\left[\mathrm{La}^{-}\right](\mathrm{p}=0.098)$ were found, when compared to cycling at $60 \mathrm{rev} \cdot \mathrm{min}^{-1}$. No significant differences in $\Delta \mathrm{VO}_{2}(\mathrm{p}=0.42), \Delta \mathrm{VCO}_{2}(\mathrm{p}=0.77)$, as well as in $\Delta\left[\mathrm{NH}_{3}\right](\mathrm{p}=0.72)$ and $\Delta\left[\mathrm{K}^{+}\right](\mathrm{p}=0.55)$ were found when cycling at 60 and $120 \mathrm{rev} \cdot \mathrm{min}^{-1}$.

Exercise-induced changes in gas exchange variables and in blood $\left[\mathrm{H}^{+}\right], \quad\left[\mathrm{HCO}_{3}^{-}\right], \quad\left[\mathrm{La}^{-}\right], \quad\left[\mathrm{NH}_{3}\right], \quad\left[\mathrm{K}^{+}\right]$ concentrations during cycling at 60 and $120 \mathrm{rev} \mathrm{min}^{-1}$ in group $H$ and in the group $L$

During cycling at $60 \mathrm{rev} \cdot \mathrm{min}^{-1}$, the exerciseinduced increases in $\mathrm{VO}_{2}, \mathrm{VCO}_{2}, \mathrm{~V}_{\mathrm{E}},\left[\mathrm{H}^{+}\right],\left[\mathrm{La}^{-}\right],\left[\mathrm{NH}_{3}\right]$ and $\left[\mathrm{K}^{+}\right]$were not significantly different between subjects from group $\mathrm{H}$ and $\mathrm{L}$. During cycling at $120 \mathrm{rev} \cdot \mathrm{min}^{-1}$, the exercise-induced increases in $\mathrm{VO}_{2}, \mathrm{VCO}_{2}, \mathrm{~V}_{\mathrm{E}},\left[\mathrm{La}^{-}\right],\left[\mathrm{K}^{+}\right]$ were not significantly different between subjects from group $\mathrm{H}$ and $\mathrm{L}$. However, in the subjects from group $\mathrm{H}$, a significantly higher $\Delta\left[\mathrm{H}^{+}\right](\mathrm{p}=0.045)$ and a tendency to a higher $\Delta\left[\mathrm{NH}_{3}\right](\mathrm{p}=0.13)$ were observed, when compared to subjects from group $\mathrm{L}$ during cycling at $120 \mathrm{rev} \cdot \mathrm{min}^{-1}$. 
Table 1. The exercise-induced changes ( $\Delta$ : the difference between the end-exercise and rest value) in oxygen uptake $\left(\Delta \mathrm{VO}_{2}\right)$, carbon dioxide production $\left(\Delta \mathrm{VCO}_{2}\right)$, minute ventilation $\left(\Delta \mathrm{V}_{\mathrm{E}}\right)$, plasma lactate concentration $\Delta\left[\mathrm{La}^{-}\right]$, plasma ammonia concentration $\Delta\left[\mathrm{NH}_{3}\right]$, blood hydrogen ion concentration $\Delta\left[\mathrm{H}^{+}\right]$, blood bicarbonate concentration $\Delta\left[\mathrm{HCO}_{3}^{-}\right]$; data obtained during the incremental cycling performed at $60 \mathrm{rev} \cdot \mathrm{min}^{-1}$ and at $120 \mathrm{rev} \cdot \mathrm{min}^{-1}$ for 19 subjects (Wilcoxon-signed-rank test for paired data with non-asymptotic, exact $\mathrm{p}$-value). In case of exercise-induced changes in plasma potassium concentration data for 17 subjects were shown.

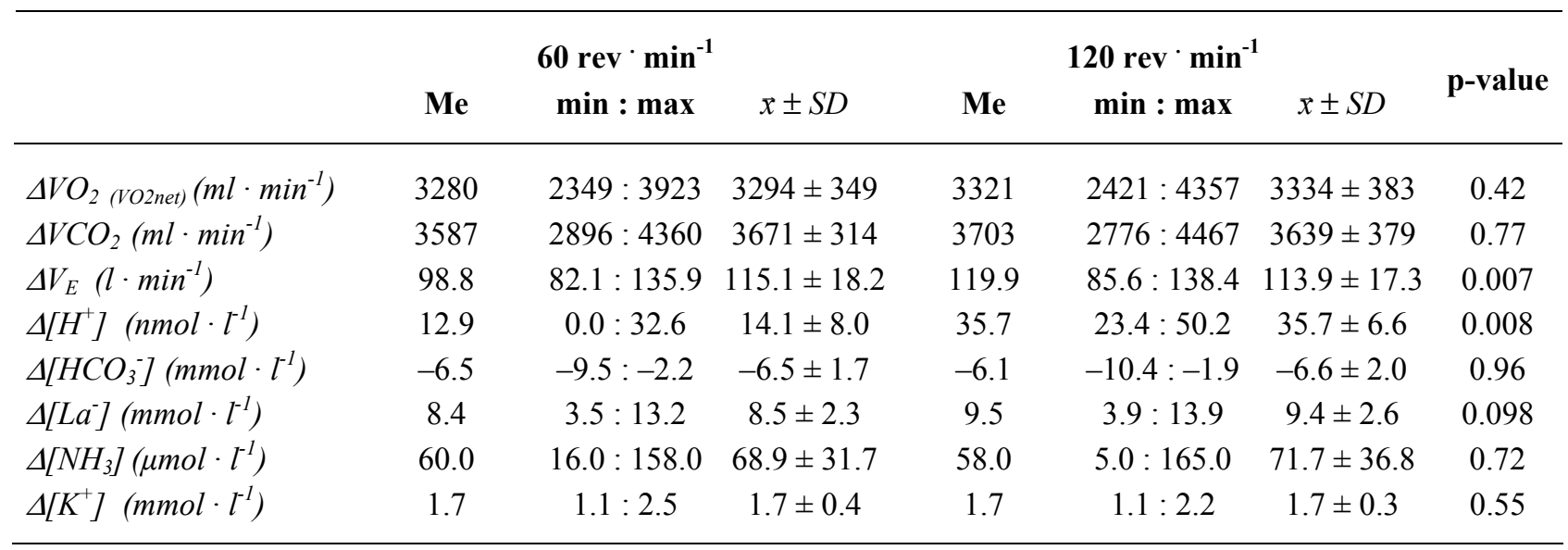

\section{Discussion}

In the present study, the power output reached by the subjects $(\mathrm{n}=19)$ at the $\mathrm{VO}_{2 \max }\left(\mathrm{P}_{\mathrm{I}, \max }\right)$ during incremental cycling performed at $120 \mathrm{rev} \cdot \mathrm{min}^{-1}$ was by $25 \%$ lower $(\mathrm{p}=0.0001)$ than during cycling at $60 \mathrm{rev} \cdot \mathrm{min}^{-1}$. Moreover, during cycling performed at $120 \mathrm{rev} \cdot \mathrm{min}^{-1}$, higher oxygen cost of generating $\mathrm{P}_{\mathrm{I}, \max }$ $(\mathrm{p}=0.009)$ was observed, when compared to the cycling at $60 \mathrm{rev} \cdot \mathrm{min}^{-1}$, which is in agreement with our previous studies (Zoladz et al. 1995, 2000). It is well known that during cycling at high pedaling rates oxygen cost of cycling at a given power output is greater, when compared to cycling at low pedaling rates (Gaesser and Brooks 1975, Sargeant and Beelen 1993, Zoladz et al. 1995). However, the reason for the lower mechanical efficiency of cycling at high pedaling rates remains unclear. The most often presented rational is higher contribution of internal work to the generated total power output (Francescato et al. 1995) and/or greater recruitment of less efficient fast muscle fibers (Leary et al. 2003) to the power generation (Sargeant and Beelen 1993, Beleen et al. 1993).

The most interesting and original finding of this study was that the $\mathrm{P}_{\mathrm{I}, \max }$ reached during incremental cycling performed at $60 \mathrm{rev} \cdot \mathrm{min}^{-1}$ in the group of subjects with lower MyHC II content in the vastus lateralis muscle was significantly higher (about $10 \%$ ), $(\mathrm{p}=0.03)$ than the $\mathrm{P}_{\mathrm{I}, \max }$ reached in the group of subjects with the higher MyHC II content in this muscle. During cycling at $120 \mathrm{rev} \cdot \mathrm{min}^{-1}$, however, the difference in the $\mathrm{P}_{\mathrm{I}}$, max between subjects from both groups was not significant $(\mathrm{p}=0.38)$. Moreover, we have shown that during incremental cycling at 60 as well as $120 \mathrm{rev} \cdot \mathrm{min}^{-1}$, in the range of the four highest power outputs completed oxygen uptake $\left(\mathrm{VO}_{2}\right)$ (Figs $1 \mathrm{~A}$ and 1B), the concentrations of blood hydrogen ion $\left[\mathrm{H}^{+}\right]$ (Figs 2A and 2B), plasma lactate [La-] (Figs 4A and 4B) and plasma ammonia $\left[\mathrm{NH}_{3}\right]$ (Figs $5 \mathrm{~A}$ and $5 \mathrm{~B}$ ) were found to be higher in subjects with higher MyHC II content in the vastus lateralis muscle, when compared to subjects with lower MyHC II content in this muscle.

These results show that the subjects with the lower content of MyHC II isoform in the vastus lateralis muscle perform relatively better, regarding the $\mathrm{P}_{\mathrm{I} \text {, max }}$, than the subjects with the higher MyHC II content in this muscle while cycling at $60 \mathrm{rev} \cdot \mathrm{min}^{-1}$. This difference, however, becomes less evident when cycling at $120 \mathrm{rev} \cdot \mathrm{min}^{-1}$. As mentioned above, during cycling at 60 as well as at $120 \mathrm{rev} \cdot \mathrm{min}^{-1}$ the oxygen uptake and the concentrations of some metabolites in blood such as $\left[\mathrm{H}^{+}\right]$, $\left[\mathrm{La}^{-}\right]$and $\left[\mathrm{NH}_{3}\right]$ associated with muscle fatigue, measured at the four highest power outputs completed were higher in the subjects with the higher content of MyHC II isoforms in the vastus lateralis muscle. This is in accordance with previous studies, involving various experimental models, showing that during muscle contractions concentration of hydrogen ion (Thorstensson and Karlsson 1976, Westerblad and Lännergren 1988), lactate (Essen and Häggmark 1975) and ammonia (Meyer and Terjung 1979, Dudley et al. 1983) are higher in fast than in slow muscle fibers.

The early fatigue observed in the subjects with the higher content of MyHC II in the vastus lateralis 
muscle during cycling at $60 \mathrm{rev} \cdot \min ^{-1}$ could be due to higher energetic cost of exercise and faster accumulation of some metabolites such as $\left[\mathrm{H}^{+}\right],\left[\mathrm{K}^{+}\right],[\mathrm{ADP}],\left[\mathrm{P}_{\mathrm{i}}\right]$, [IMP], $\left[\mathrm{NH}_{3}\right]$ in the muscle (Dawson et al. 1980, Fitts 1994, Allen et al. 1995, Sahlin et al. 1998, Woledge 1998). One may also consider an increased rate of production of the reactive oxygen species in the type II muscle fibers (Alessio et al. 1988, Anderson and Neufer 2006), which has been suggested as a potential factor contributing to muscle fatigue (Reid et al. 1992, Arbogast and Reid 2004, Medved et al. 2004, Juel 2006), especially at physiological temperatures (Moopanar and Allen 2005). Surprisingly, in our study during cycling at $120 \mathrm{rev} \cdot \mathrm{min}^{-1}$, despite a higher concentrations of $\left[\mathrm{H}^{+}\right]$, $\left[\mathrm{La}^{-}\right]$and $\left[\mathrm{NH}_{3}\right]$ in blood, as observed at the four highest power outputs completed in the subjects with the higher MyHC II content in the vastus lateralis (Figs 2B, 4B and $5 \mathrm{~B})$, the $\mathrm{P}_{\mathrm{I}, \max }$ was not significantly different $(\mathrm{p}=0.38)$ from that found in the subjects with the lower content of MyHC II in this muscle. This result suggests that, especially during cycling at high pedaling rates, the maximal power generating capabilities of the muscles with higher MyHC II isoforms content are less affected by the "fatiguing metabolites" than the muscles with lower MyHC II isoforms content. The reason for that is unknown but some explanations have been put forward.

It should be mentioned that some authors questioned the role of the hydrogen ion as a main factor responsible for muscle fatigue at physiological temperature (Pate et al. 1995, Westerblad et al. 1997). It is even suggested (Nielsen et al. 2001, Pedersen et al. 2004) that the intracellular hydrogen ion and lactate accumulation might have a protective function in muscle during activity, because they counteract the effects of the exercise-induced increase in extracellular potassium concentration, considered as one of the candidates of muscle fatigue (Sjögaard 1990, Fitts 1994).

It should be noted that in our study during incremental cycling performed at $120 \mathrm{rev} \cdot \mathrm{min}^{-1}$ we have observed a tendency $(p=0.13)$ towards higher exerciseinduced increase in ammonia concentration in subjects with higher MyHC II content in the vastus lateralis when compared to subjects with lower MyHC II content in this muscle. It has been known for a long time that working muscles produce ammonia (Parnas 1929) and the main source of ammonia during intense exercise is AMP deamination (Tullson and Terjung 1990). According to Korzeniewski (2006) the adenylate kinase and AMP deaminase reaction decrease the amount of ADP and lower activation of anaerobic glycolysis, therefore slowdown muscle acidification during high intensity exercise. Moreover, one could consider that production of ammonia during exercise may not necessary be harmful to the muscle, as suggested previously (Banister and Cameron 1990), since at the muscle $\mathrm{pH}$ below 7.0, $\mathrm{NH}_{3}$ may act as proton acceptor contributing to the attenuation of exercise-induced acidosis. However, the capacity of buffering $\mathrm{H}^{+}$by ammonia is rather limited (Graham et al. 1995). Therefore, higher accumulation of ammonia in subjects with higher MyHC II content in the vastus lateralis muscle could play only a minor protective role in acid-base status of the muscle during cycling at high muscle shortening velocity.

As presented in Figure 1A, significantly higher $\mathrm{VO}_{2}$ at a given power output during cycling at $60 \mathrm{rev} \cdot \mathrm{min}^{-1}$ was found in the group of subjects with the higher MyHC II content in the vastus lateralis muscle when compared to the subjects with the lower MyHC II content in this muscle. A similar tendency was also observed during cycling at $120 \mathrm{rev} \cdot \mathrm{min}^{-1}$ (Fig. 1B). This observation is in agreement with our previous studies showing the relationship between oxygen cost of cycling and MyHC II content in the vastus lateralis muscle (Zoladz et al. 2002, Majerczak et al. 2006). The higher oxygen cost of generating power in subjects with higher MyHC II content in the vastus lateralis muscle in our study could be related to lower efficiency of type II muscle fibers mitochondria (Leary et al. 2003). However, it should be noted that data concerning the efficiency of different muscle fiber types are inconsistent (Suzuki 1979, Medbø 1990, Coyle et al. 1992, Horowitz et al. 1994) and muscle fiber type efficiency is probably related to the intensity and muscle contraction velocity (Sargeant and Beelen 1993, Sargeant and Jones 1995).

When discussing the effect of muscle fiber composition on the power generating capabilities and energy cost of work, one has to consider the effect of muscle shortening velocity on the muscle efficiency of various muscle fibers. According to the model presented by Sargeant and Jones (1995), the optimal velocity of contractions of type I muscle fibers during cycling exercise is about $60 \mathrm{rev} \cdot \mathrm{min}^{-1}$, whereas the optimal shortening velocity of type II muscle fibers lies above $120 \mathrm{rev} \cdot \mathrm{min}^{-1}$. Therefore, the subjects who possess predominantly type I muscle fibers perform, during cycling at $60 \mathrm{rev} \cdot \mathrm{min}^{-1}$, closely to the optimal contraction velocity, hence they can generate a given external mechanical power output at a lower energy cost. 
However, cycling at high pedaling rates $\left(120 \mathrm{rev} \cdot \mathrm{min}^{-1}\right)$ that exceed the optimal contraction velocities of type I muscle fibers, is more preferential in terms of power generation capabilities and the mechanical efficiency for the subjects who possess high content of type II muscle fibers with much higher optimal shortening velocity (Sargeant and Beelen 1993, Sargeant and Jones 1995). This consideration is in agreement with the experimental data obtained in the present study.

We have concluded that during maximal incremental exercise performed at low pedaling rates the subjects with the lower content of MyHC II possess greater power generating capabilities than the subjects with the higher content of MyHC II in the vastus lateralis muscle. Surprisingly, at high pedaling rate, power generating capabilities in the subjects with higher MyHC II content in the vastus lateralis muscle did not differ from those found in the subjects with the lower content of MyHC II in this muscle, despite higher blood $\left[\mathrm{H}^{+}\right],\left[\mathrm{La}^{-}\right]$and $\left[\mathrm{NH}_{3}\right]$ concentrations. This indicates that at high pedaling rates the subjects with higher percentage of MyHC II in the vastus lateralis muscle perform relatively better than the subjects with lower percentage of MyHC II in this muscle.

\section{Conflict of Interest}

There is no conflict of interest.

\section{Acknowledgements}

The study was supported by funds from University School of Physical Education, Krakow (grant No: $182 / \mathrm{IFC} / 2004$ ) and by funds for the statutory research in 2007 for the Department of Physiology and Biochemistry, University School of Physical Education, Krakow, Poland.

\section{References}

AAGAARD P, ANDERSEN JL: Correlation between contractile strength and myosin heavy chain isoform composition in human skeletal muscle. Med Sci Sports Exerc 30: 1217-1222, 1998.

ALESSIO HM, GOLDFARB AH, CUTLER RG: MDA content increases in fast- and slow-twitch skeletal muscle with intensity of exercise in a rat. Am J Physiol 255: C874-C877, 1988.

ALLEN DG, LÄNNERGREN J, WESTERBLAD H: Muscle cell function during prolonged activity: cellular mechanisms of fatigue. Exp Physiol 80: 497-527, 1995.

ANDERSEN JL, AAGAARD P: Myosin heavy chain IIX overshoot in human skeletal muscle. Muscle Nerve 23: 1095 $1104,2000$.

ANDERSON EJ, NEUFER PD: Type II skeletal myofibers possess unique properties that potentiate mitochondrial $\mathrm{H}_{2} \mathrm{O}_{2}$ generation. Am J Physiol 290: C844-C851, 2006.

ARBOGAST S, REID MB: Oxidant activity in skeletal muscle fibers is influenced by temperature, $\mathrm{CO}_{2}$ level, and muscle-derived nitric oxide. Am J Physiol 287: R698-R705, 2004.

ASTRAND P-O, RODAHL K: Evaluation of physical performance on the basis of tests. In: Textbook of Work Physiology. Physiological Basis of Exercise. MD PROVENZANO (ed), McGraw-Hill, New York, 1986, pp 354-390.

BANISTER EW, CAMERON BJ: Exercise-induced hyperammonemia: peripheral and central effects. Int J Sports Med 11 (Suppl 2): S129-S142, 1990.

BEELEN A, SARGEANT AJ, LIND A, DE HAAN A, KERNELL D, VAN MECHELEN W: Effect of contraction velocity on the pattern of glycogen depletion in human muscle fibre types. In: Neuromuscular Fatigue. AJ SARGEANT, D KERNELL (eds), North Holland, Amsterdam, 1993, pp 93-95.

CARRARO U, CATANI C: A sensitive SDS-PAGE method separating myosin heavy chain isoforms of rat skeletal muscles reveals the heterogeneous nature of the embryonic myosin. Biochem Biophys Res Commun 11: 793 $802,1983$.

COYLE EF, SIDOSSIS LS, HOROWITZ JF, BELTZ JD: Cycling efficiency is related to the percentage of type I muscle fibers. Med Sci Sports Exerc 24: 782-788, 1992.

DAWSON MJ, GADIAN DG, WILKIE DR: Mechanical relaxation rate and metabolism studied in fatiguing muscle by phosphorus nuclear magnetic resonance. J Physiol Lond 299: 465-484, 1980.

DUDLEY GA, STARON RS, MURRAY TF, HAGERMAN FC, LUGINBUHL A: Muscle fiber composition and blood ammonia levels after intense exercise in humans. J Appl Physiol 54: 582-586, 1983. 
ESSEN B, HÄGGMARK T: Lactate concentration in type I and II muscle fibres during muscular contraction in man. Acta Physiol Scand 95: 344-346, 1975.

FITTS RH: Cellular mechanisms of muscle fatigue. Physiol Rev 74: 49-94, 1994.

FRANCESCATO MP, GIRARDIS M, DI PRAMPERO PE: Oxygen cost of internal work during cycling. Eur J Appl Physiol Occup Physiol 72: 51-57, 1995.

FRY AC, ALLEMEIER CA, STARON RS: Correlation between percentage fiber type area and myosin heavy chain content in human skeletal muscle. Eur J Appl Physiol Occup Physiol 68: 246-251, 1994.

HOROWITZ JF, SIDOSSIS LS, COYLE EF: High efficiency of type I muscle fibers improves performance. Int $J$ Sports Med 15: 152-157, 1994.

GAESSER GA, BROOKS GA: Muscular efficiency during steady-rate exercise: effects of speed and work rate. $J$ Appl Physiol 38: 1132-1139, 1975.

GRAHAM TE, RUSH JWE, MCLEAN DA: Skeletal muscle amino acids metabolism and ammonia production during exercise. In: Exercise Metabolism. M HARGREAVES (ed), Human Kinetics Publishers, Champaign, 1995, pp 131-175.

JUEL C: Muscle fatigue and reactive oxygen species. J Physiol Lond 576: 1, 2006.

KORZENIEWSKI B: AMP deamination delays muscle acidification during heavy exercise and hypoxia. $J$ Biol Chem 281: 3057-3066, 2006.

LEARY SC, LYONS CN, ROSENBERGER AG, BALLANTYNE JS, STILLMAN J, MOYES CD: Fiber-type differences in muscle mitochondrial profiles. Am J Physiol 285: R817-R826, 2003.

MAJERCZAK J, SZKUTNIK Z, KARASINSKI J, DUDA K, KOLODZIEJSKI L, ZOLADZ JA: High content of MyHC II in vastus lateralis is accompanied by higher $\mathrm{VO}_{2}$ /power output ratio during moderate intensity cycling performed both at low and at high pedalling rates. J Physiol Pharmacol 57: 199-215, 2006.

MATHESON GO, ALLEN PS, ELLINGER DC, HANSTOCK CC, GHEORGHIU D, MCKENZIE DC, STANLEY C, PARKHOUSE WS, HOCHACHKA PW: Skeletal muscle metabolism and work capacity: a ${ }^{31}$ P-NMR study of Andean natives and lowlanders. J Appl Physiol 70: 1963-1976, 1991.

MEDBØ JI: Type I and type II fibres work with the same mechanical efficiency during bicycling. In: Muscle and Motility. G MARECHAL, U CARRARO (eds), Intercept, Andover, UK, 1990, pp 303-308.

MEDVED I, BROWN MJ, BJORKSTEN AR, MURPHY KT, PETERSEN AC, SOSTARIC S, GONG X, MCKENNA MJ: N-acetylcysteine enhances muscle cysteine and glutathione availability and attenuates fatigue during prolonged exercise in endurance-trained individuals. J Appl Physiol 97: 1477-1485, 2004.

MEYER RA, TERJUNG RL: Differences in ammonia and adenylate metabolism in contracting fast and slow muscle. Am J Physiol 237: C111-C118, 1979.

MOOPANAR TR, ALLEN DG: Reactive oxygen species reduce myofibrillar $\mathrm{Ca}^{2+}$ sensitivity in fatiguing mouse skeletal muscle at 37 degrees C. J Physiol Lond 564: 189-199, 2005.

NIELSEN OB, DE PAOLI F, OVERGAARD K: Protective effects of lactic acid on force production in rat skeletal muscle. J Physiol Lond 536: 161-166, 2001.

PARNAS JK: Über die Ammoniakbildung im Muskel und ihren Zusammenhang mit Funktion und Zustandsänderung. Der Zusammenhang der Ammoniakbildung mit der Umwandlung des Adeninnucleotids zu Inosinsäure. Biochem Z 206: 16-38, 1929.

PATE E, BHIMANI M, FRANKS-SKIBA K, COOKE R: Reduced effect of $\mathrm{pH}$ on skinned rabbit psoas muscle mechanics at high temperatures: implications for fatigue. J Physiol Lond 486: 689-694, 1995.

PEDERSEN TH, NIELSEN OB, LAMB GD, STEPHENSON DG: Intracellular acidosis enhances the excitability of working muscle. Science 305: 1144-1147, 2004.

REID MB, HAACK KE, FRANCHEK KM, VALBERG PA, KOBZIK L, WEST MS: Reactive oxygen in skeletal muscle. I. Intracellular oxidant kinetics and fatigue in vitro. J Appl Physiol 73: 1797-1804, 1992.

SAHLIN K, TONKONOGI M, SODERLUND K: Energy supply and muscle fatigue in humans. Acta Physiol Scand 162: 261-266, 1998.

SARGEANT AJ, HOINVILLE E, YOUNG A: Maximum leg force and power output during short-term dynamic exercise. J Appl Physiol 51: 1175-1182, 1981. 
SARGEANT AJ, BEELEN A: Human muscle fatigue in dynamic exercise. In: Neuromuscular Fatigue. AJ SARGEANT, D KERNELL (eds), North Holland, Amsterdam, 1993, pp 81-92.

SARGEANT AJ: Human power output and muscle fatigue. Int J Sports Med 15: 116-121, 1994.

SARGEANT AJ, JONES DA: The significance of motor unit variability in sustaining mechanical output of muscle. In: Fatigue. Neural and muscular mechanism. SC GANDEVIA, RM ENOKA, AJ MCCOMAS, DG STUART, CHK THOMAS (eds), Plenum Press, New York, 1995, pp 323-338.

SARGEANT AJ, DE HAAN A: Human muscle fatigue: the significance of muscle fibre type variability studied using a micro-dissection approach. J Physiol Pharmacol 57 (Suppl 10): 5-16, 2006.

SJÖGAARD G: Exercise-induced muscle fatigue: the significance of potassium. Acta Physiol Scand Suppl 593: 1-63, 1990.

SEBER GAF: Linear Regression Analysis. John Wiley, New York, 1977.

SUZUKI Y: Mechanical efficiency of fast and slow - twitch muscle fibers in man during cycling. J Appl Physiol 47: 263-267, 1979.

THORSTENSSON A, KARLSSON J: Fatiguability and fibre composition of human skeletal muscle. Acta Physiol Scand 98: 318-322, 1976.

TULLSON PC, TERJUNG RL: Adenine nucleotide degradation in striated muscle. Int J Sports Med 11 (Suppl 2): S47S55, 1990.

WESTERBLAD H, LÄNNERGREN J: The relation between force and intracellular $\mathrm{pH}$ in fatigued, single Xenopus muscle fibres. Acta Physiol Scand 133: 83-89, 1988.

WESTERBLAD H, BRUTON JD, LÄNNERGREN J: The effect of intracellular $\mathrm{pH}$ on contractile function of intact, single fibres of mouse muscle declines with increasing temperature. J Physiol Lond 500: 193-204, 1997.

WILMORE JH, COSTILL DL: Energy for movement. In: Physiology of Sport and Exercise. H GILLY, J RHODA, S MERZ BOTT, K BOJDA (eds), Human Kinetics Publishers, Champaign, 1999, pp 113-154.

WOLEDGE RC: Possible effects of fatigue on muscle efficiency. Acta Physiol Scand 162: 267-273, 1998.

ZOLADZ JA, RADEMAKER AC, SARGEANT AJ: Non-linear relationship between $\mathrm{O}_{2}$ uptake and power output at high intensities of exercise in humans. $J$ Physiol 488: 211-217, 1995.

ZOLADZ JA, RADEMAKER AC, SARGEANT AJ: Human muscle power generating capability during cycling at different pedalling rates. Exp Physiol 85: 117-124, 2000.

ZOLADZ JA, DUDA K, KARASINSKI J, MAJERCZAK J, KOLODZIEJSKI L, KORZENIEWSKI B: MyHC II content in the vastus lateralis $\mathrm{m}$. quadricipitis femoris is positively correlated with the magnitude of the nonlinear increase in the $\mathrm{VO}_{2}$ / power output relationship in humans. J Physiol Pharmacol 53: 805-821, 2002.

ZOLADZ JA, KORZENIEWSKI B, GRASSI B: Training-induced acceleration of oxygen uptake kinetics in skeletal muscle: the underlying mechanisms. J Physiol Pharmacol 57 (Suppl 10): 67-84, 2006. 